\title{
Penerapan Media Audiovisual dalam Pembelajaran Menulis Karangan Bahasa Jepang (Sakubun)
}

\author{
${ }^{1}$ Noviyanti Aneros, ${ }^{2}$ Intan Permatasari, ${ }^{3}$ Aep Saeful Bachri, ${ }^{4}$ Juju Juangsih \\ Universitas Pendidikan Indonesia, Indonesia
}

\author{
1aneros.noviyanti@upi.edu \\ 2ipermatasari545@gmail.com \\ 3aepsaefulbachri@upi.edu \\ 4jujujuangsih@upi.edu
}

DOI: $10.18196 /$ jjlel.4239

\begin{abstract}
Abstrak
Keterbatasan ide/gagasan, kurangnya penguasaan kosakata dan gramatika bahasa Jepang menjadi faktor penyebab pembelajar bahasa Jepang mengalami kesulitan untuk menuangkan dan mengembangkan ide ketika menulis karangan bahasa Jepang (sakubun). Penelitian ini bertujuan untuk mengetahui apakah media audiovisual dapat membantu pembelajar untuk menuangkan dan mengembangkan ide/gagasan ketika menulis karangan bahasa Jepang (sakubun). Pengumpulan dan analisis data diperoleh dengan menggunakan metode kuasi eksperimen dengan rancangan One Grup Pre-Test and Post-test Design. Penelitian ini melibatkan 19 orang pembelajar bahasa Jepang yang sedang mengambil mata kuliah menulis tingkat menengah (chukyu sakubun) di salah satu universitas di Bandung. Instrumen pengambilan data menggunakan tes tulis, observasi dan angket. Dari hasil analisis data terbukti bahwa ada kenaikan nilai rata-rata secara signifikan setelah menggunakan media audiovisual pada pembelajaran sakubun, yaitu dilihat dari nilai rata-rata pretest, 54,5 menjadi 86,1 untuk rata-rata nilai posttest. Selain itu, data angket menunjukkan sebagian besar pembelajar setuju, penggunaan media audiovisual dapat membantu mereka dalam pembelajaran menulis karangan bahasa Jepang (sakubun).
\end{abstract}

Kata kunci: audiovisual; karangan bahasa Jepang(sakubun); mengembangkan ide; Youtube 


\begin{abstract}
Limitation of an idea/notion, and lack of Japanese grammar and vocabulary mastery become causative factors for Japanese language learners in having difficulty in pouring dan developing ideas into Japanese writing essays (Sakubun). This study aims to identify the use of audiovisual media for Japanese learners in pouring and developing ideas into Japanese writing essays (Sakubun). Data collection and analysis were conducted using a quasi-experimental method with One Group Pre-Test and Post-Test Design. This study involved 19 Japanese learners who were enrolled in intermediate writing courses (Chukyu Sakubun) at a university in Bandung. Data collection instruments used written tests, observations, and questionnaires. Based on the results of data analysis, it showed that there was a significant increase in the average value after using audiovisual media in sakubun learning. It was revealed in the average pretest score from 54.5 to 86.1 for the average posttest score. Furthermore, questionnaire data showed that most learners agreed that the use of audiovisual media could help them learn Japanese writing essays (sakubun).
\end{abstract}

Keywords: audiovisual; developing ideas; Japanese writing (sakubun); Youtube

\title{
PENDAHULUAN
}

Menulis merupakan suatu kegiatan yang mengaplikasikan kemampuan menyampaikan pandangan, buah fikiran atau perasaan ke dalam bentuk tulisan kepada pembaca (Abbas, 2006). Selanjutnya, Anshori (2004) berpendapat bahwa kemampuan berbahasa seseorang dapat dilihat dari kemampuan menulis. Oleh karena itu, menulis merupakan inti pembelajaran bahasa meskipun ditempatkan pada urutan terakhir setelah membaca, mendengar dan berbicara. Akan tetapi berdasarkan hasil dari beberapa penelitian menunjukkan bahwa sedikit mahasiswa dapat mengimplementasikan kemampuan menulis sehingga mereka mengalami kesulitan yang dapat menyebabkan rendahnya kemampuan berkomunikasi secara tulisan. Cahyani (2005) mengungkapkan kesulitan mahasiswa dalam menulis, seperti kekhawatiran akan membuat kesalahan ketika memulai dan menulis sebuah topik, rendahnya kemampuan membuat komposisi karangan, menuangkan kalimat-kalimat di bagian pembuka, kalimat-kalimat di bagian simpulan, mengembangkan paragraf, dan menerapkan dengan tepat unsurunsur karangan, seperti wahana dan tatanan. Begitu pula hal ini terjadi pada 
mahasiswa yang mengontrak mata kuliah sakubun (menulis karangan) dalam Bahasa Jepang sering dianggap sebagai mata kuliah yang paling sulit, baik oleh pembelajar ataupun pengajar. Keharusan menuangkan dan mengembangkan ide/gagasan, mengaplikasikan pola kalimat yang terdapat pada buku ajar, penulisan huruf kanji, ungkapan, dan penggunaan partikel ketika akan menyampaikan suatu ide atau gagasan ke dalam bentuk tulisan bahasa Jepang merupakan hal yang paling menyulitkan (Aneros, 2013). Seperti halnya pendapat Abbas (2006) menjelaskan bahwa keterkaitan antara ketepatan menuangkan ide dengan ketepatan penggunaan bahasa, kosakata, tata bahasa dan ejaan merupakan hal penting pada kegiatan menulis. Selain itu, pembelajaran sakubun harus sesuai dengan tujuan pembelajaran yang ditetapkan oleh universitas ini, pembelajar diharapkan dapat menulis karangan dengan menggunakan, mengaplikasikan, kosakata, tata bahasa, dan ungkapan pada level menengah tinggi dengan tema karangan mengenai sosial, ekonomi, budaya dan teknologi. Juga dapat membuat tulisan dengan media online seperti menulis email dan membuat blog (Widianti, dkk,2019). Penggunaan media pada pembelajaran sakubun dapat menjalin hubungan antara pengajar dengan mahasiswa secara optimal sehingga prestasi belajar yang dicapai selaras dengan tujuan pembelajaran.

Maka dari itu, agar pembelajar mampu secara mudah menuangkan dan mengembangkan gagasan sesuai dengan topik yang di tentukan, pengajar harus memberikan stimulus untuk merangsang kinerja otak. Banyak media yang dapat menstimulus pembelajar dalam kegiatan pembelajaran di sekolah seperti media visual (gambar atau buku), media audio (tape recorder) dan media audiovisual (video atau film) dalam kegiatan pembelajaran (Hermawan, 2007). Beberapa penelitian telah menggunakan media dalam menyelesaikan beberapa permasalahan seputar pembelajaran sakubun. Salah satunya adalah penggunaan media komik tanpa dialog, gambar iklan dan lagu pada pembelajaran sakubun. Pengajaran sakubun menggunakan media tersebut lebih efektif karena pembelajar dapat mengembangkan sebuah gagasan 
sederhana menjadi banyak dan beragam (Novianti, 2012). Selanjutnya, penelitian Aneros (2012) menunjukkan bahwa pembelajaran sakubun melalui pendekatan Contextual Teaching and Learning (CTL) memberikan hasil yang positif. Kemampuan mahasiswa dalam mengembangkan karangannya meningkat, berbagai ide dan berbagai hal yang dilihat secara langsung (realia) dapat dengan mudah dituangkan ke dalam karangannya. Hal ini menunjukkan bahwa dengan suatu strategi dan media yang tepat maka tujuan pembelajaran pun tercapai. Media-media yang tersedia dapat menjadi alternatif dalam pengajaran, khususnya dalam bahasa Jepang. Berkaitan dengan hal ini, penggunaan media seperti teknik drama atau hiburan berfungsi untuk memotivasi minat atau memberikan stimulus siswa untuk bertindak. Selain itu, media berfungsi juga untuk menyajikan informasi sebagai pengantar atau ringkasan kepada sekelompok siswa (Kempt dan Dayton, 1998).

Pada saat ini, salah satu media yang diminati oleh pembelajar adalah dengan menggunakan media audiovisual atau dapat disebut video. Media audiovisual tidak hanya mengandalkan kemampuan visual saja, namun ditambah dengan audio yang bisa memberikan seolah-olah pengalaman nyata bagi yang melihat. Hal tersebut akan membantu siswa yang merasa bosan dengan pembelajaran yang hanya bersumber dari buku pelajaran saja.

Dilatarbelakangi masalah-masalah diatas, peneliti membuat sebuah gagasan untuk menerapkan media audiovisual video yang berasal dari situs Youtube sebagai media yang dapat membantu pembelajar bahasa Jepang untuk mengatasi kendala pengembangan gagasan dalam keterampilan menulis karangan bahasa Jepang (sakubun) tingkat III.

\section{METODE PENELITIAN}

Jenis penelitian yang digunakan adalah metode kuasi eksperimen (Quasi Eksperiment Method). Pelaksanaan Pre-Test and Post-test Design ini bertujuan untuk mengetahui bagaimana perkembangan kemampuan menulis sakubun mahasiswa terhadap penggunaan media audiovisual. Penelitian ini 
melibatkan 19 orang pembelajar bahasa Jepang yang sedang mengambil mata kuliah menulis tingkat menengah (chukyu sakubun) di salah satu universitas di Bandung. Teknik pengumpulan data pada penelitian ini menggunakan tes dan nontes. Pre-test dan Post-test merupakan instrument tes, sedangkan instrumen nontes berupa angket diberikan kepada pembelajar untuk mengetahui respon setelah pembelajaran menggunakan media audiovisual video dan lembaran observasi. Sedangkan treatment dilaksanakan sebanyak tiga kali. Setiap treatment diberikan berupa penerapan media audiovisual dalam bentuk video. Adapun tahapan yang dilakukan pada saat treatment sebagai berikut: 1) peneliti bertanya tentang pengalaman pembelajar sesuai materi pembelajaran yang akan di sampaikan, 2) peneliti menyajikan materi pembelajaran dengan media video (Youtube), 3) Setelah menyajikan materi pembelajaran, peneliti membahas apa saja yang ada dalam video tersebut, 4) Setelah itu meneliti tentang kosakata yang ada dalam video, dan pembelajar bisa bertanya bila tidak tahu, 5) Penugasan kepada pembelajar untuk menulis karangan sesuai tema pada setiap pertemuan, dan 6) Diadakan evaluasi pembelajaran di akhir treatment.

Oomori dan Kono (2013) berpendapat bahwa pada pembelajaran sakubun ada lima aspek penting dan yang harus diperhatikan ketika membuat sebuah karangan, yaitu 1) pola kalimat (文法) sebanyak 30\%；2) perbendaharaan kata（語彙） sebanyak $20 \% ; 3$ ) isi cerita（内容） sebanyak 20\%; 4) kata ungkapan（表現） sebanyak 20\%; dan 5) pemakaian huruf kanji（漢字） sebanyak 10\%. Komposisi aspek yang dinilai pada penelitian ini mengadopsi teori Oomori dan Kono, sedangkan untuk bobot persentasenya dirubah disesuaikan dengan tema penelitian, yaitu penggunaan media audiovisual untuk membantu mahasiswa dalam menuangkan dan mengembangkan ide/gagasan, seperti yang terdapat pada tabel 1. 


\begin{tabular}{lc}
\hline \multicolumn{1}{c}{ Aspek } & Komposisi \\
\hline Pola Kalimat & $20 \%$ \\
Perbendaharaan kata & $20 \%$ \\
Isi cerita & $40 \%$ \\
Kata ungkapan & $10 \%$ \\
Huruf kanji & $10 \%$
\end{tabular}

Tabel 1: Aspek dan Komposisi Penilaian

Berikut adalah pola kalimat yang digunakan, sesuai dengan tema di setiap pertemuan, 1) Pertemuan pertama: 〜とくらべて, 〜ほど, まず〜次に 〜, また、〜, そのため、〜,だが、〜, dan 〜すぎる; 2) Pertemuan kedua: 〜 から〜まで, 〜なら, 〜ために, dan まず〜.

\section{HASIL DAN PEMBAHASAN}

Berdasarkan hasil pengolahan data tes, observasi dan angket, peneliti menjabarkan hasil peneltian ini menjadi dua bagian, yaitu: 1) hasil pengamatan, dan 2) hasil analisis data.

\section{Hasil Pengamatan}

Dalam penelitian ini dilakukan dua kali treatment. Materi yang digunakan adalah video-video yang ada di Youtube dengan tema karangan yaitu 1) mono no katachi, jyutai, basho, dan 2) monogoto no shikumi, tejun, houhou, $d$. Selama dua kali pertemuan tersebut, peneliti melakukan observasi terhadap peningkatan kemampuan menuangkan gagasan/ide ke dalam karangan bahasa Jepang. Pada setiap treatment peneliti menerapkan media audiovisual berupa pemutaran video (Gambar 1 dan 2) untuk memberi stimulus visual sebagai persiapan menulis sakubun. 


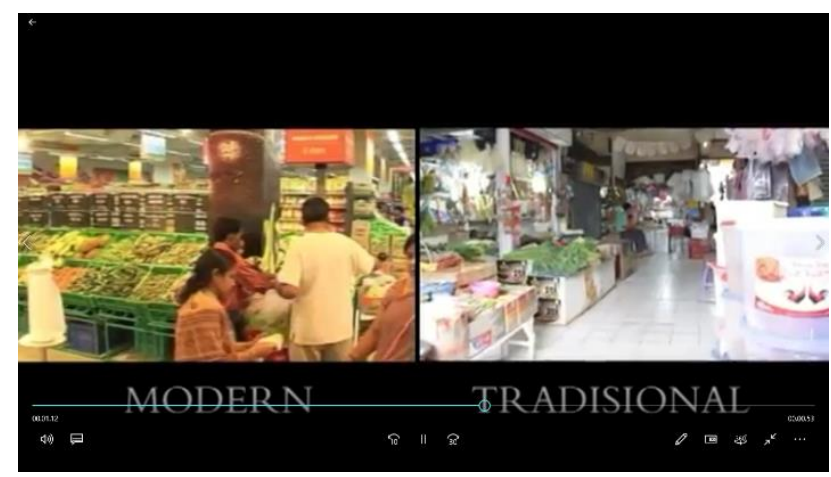

Gambar 1: Screenshoot video pasar modern dan pasar tradisional

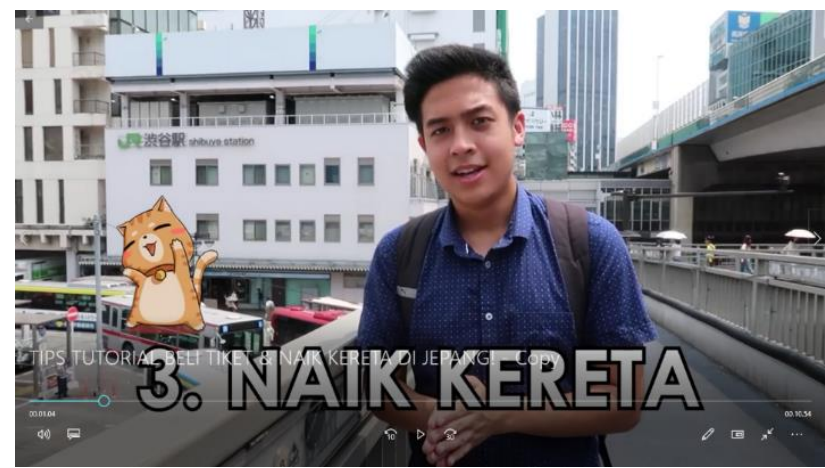

Gambar 2: Screenshoot video tutorial menggunakan kereta di Jepang

Proses pemberian treatment berjalan lancar, setelah melakuakn treatment sebanyak dua kali, perubahan pun mulai terlihat. Hal ini tampak dari hasil tulisan pembelajar yang mulai bisa mengembangkan ide sesuai dengan tema yang sedang dipelajari. Setelah diterapkannya treatment menggunakan media audiovisual video dengan menulis sebuah karangan sesuai dengan tema video yang di putar. Berdasarkan hasil pengamatan selama proses kegiatan pembelajaran sakubun menggunakan media audiovisual terlihat aktif. Partisipasi setiap pembelajar tampak ketika pengajar penayangkan video Youtube di awal pembelajaran. Hal ini membuat pembelajar dapat saling tukar menukar informasi mengenai kosa kata bahasa Jepang yang mereka kuasai sehingga suasana kelas pun menjadi lebih hidup dan menyenangkan. Pada dua kali pertemuan penyajian video Youtube, mahasiswa terlihat lebih interaktif, lebih tertarik, memiliki rasa ingin tahu dan rasa penasaran lebih dari pada hanya sebatas gambar yang ada di buku ajar. Setiap pembelajar terlihat saling 
membantu satu sama lain, seperti tukar pendapat mengenai penggunaan kosa kata, pengetahuan tentang tema yang sedang ditanyangkan di Youtube membuat mereka lebih mudah untuk menuangkan gagasan dalam menulis sakubun. Pada saat dilakukan treatment pertama peneliti memberikan video yang berdurasi sangat pendek dan tidak rinci, sedangkan pada treatment ke dua peneliti memberikan tayangan video yang berdurasi 10 menit, dan isi video itu sangat rinci dan relevan sesuai dengan tema yang sedang diajarkan, setelah diperlihatkan video, mahasiswa mendiskusikan apa yang telah dilihat, lalu mereka menuliskan poin-poin penting yang akan dikembangkan di dalam karangannya.

\section{Hasil Analisis Data}

Untuk membuktikan pengaruh penggunaan media audiovisual dalam meningkatkan keterampilan menulis karangan bahasa Jepang, berikut akan dijelaskan beberapa eksperimen yang dilakukan, termasuk pretest, post test dan angket. Aspek yang dinilai pada nilai pre-test dan post-test mengacu pada teori Oomori dan Kono akan tetapi bobot prosentasenya dirubah mengikuti tujuan dari penelitian ini, seperti yang tercantum pada tabel 1 . Untuk penilaian karangan dibuat rubrik seperti pada tabel 2 dan skala penilaian karangan pada tabel 3. Hasil perhitungan data secara keseluruhan dari pretest dan post-test seperti yang tertera pada tabel 4 .

\begin{tabular}{|c|c|c|}
\hline Aspek & Skor & Kriteria \\
\hline \multirow{4}{*}{ Isi Cerita } & 5 & Informasi yang luas, sesuai dengan tema yang diteliti (<400 字) \\
\hline & 4 & Informasi yang cukup, sesuai dengan tema yang diteliti (400 字) \\
\hline & 3 & $\begin{array}{l}\text { Informasi yang cukup, perkembangan terbatas, sesuai dengan } \\
\text { tema yang diteliti. ( } 300 \text { 字) }\end{array}$ \\
\hline & 2 & $\begin{array}{l}\text { Informasi yang cukup, perkembangan terbatas, tidak seusuai } \\
\text { dengan tema yang diteliti ( } 200 \text { 字) }\end{array}$ \\
\hline
\end{tabular}


1 Informasi terbatas, tidak berkembang, tidak sesuai dengan tema yang diteliti (100 字)

\begin{tabular}{|c|c|c|}
\hline \multirow[t]{5}{*}{ kosakata } & 5 & Kosakata yang digunakan sangat tepat dan jelas \\
\hline & 4 & Sebagian kosakata yang digunakan tepat dan jelas \\
\hline & 3 & Sebagian kosakata yang digunakan kurang tepat \\
\hline & 2 & Sebagian besar kosakata yang digunakan kurang tepat \\
\hline & 1 & Semua kosakata yang digunakan tidak tepat dan jelas \\
\hline \multirow[t]{5}{*}{ Tata Bahasa } & 5 & kailmat kompleks dengan ragam pola kalimat yang sudah diterima \\
\hline & 4 & $\begin{array}{l}\text { Kalimat sederhana dengan menggunakan pola kalimat yang sudah } \\
\text { dipelajari }\end{array}$ \\
\hline & 3 & $\begin{array}{l}\text { Kalimat sederhana dengan upaya mengaplikasikan pola kalimat } \\
\text { yang baru }\end{array}$ \\
\hline & 2 & $\begin{array}{l}\text { Kalimat sederhana tetapi ada sebagian menggunakan pola kalimat } \\
\text { yang salah }\end{array}$ \\
\hline & 1 & $\begin{array}{l}\text { Kalimat pendek dengan hampir semua pola kalimat tidak tepat } \\
\text { (tidak ada usaha untuk menggunakan bahasa baru) }\end{array}$ \\
\hline \multirow[t]{5}{*}{ Ungkapan } & 5 & Ungakapn yang sangat baik sesuai dengan tema \\
\hline & 4 & Ungkpan lumayan baik sesuai dengan tema \\
\hline & 3 & Ungkapan lumayan baik namun sebagian tidak sesuai tema \\
\hline & 2 & Ungkapan terbatas sebagian tidak sesuai tema \\
\hline & 1 & $\begin{array}{l}\text { Ungkpan sangat terbatas tidak sesuai dengan tema (tidak ada } \\
\text { usaha) }\end{array}$ \\
\hline \multirow[t]{5}{*}{$\begin{array}{l}\text { Penggunaan } \\
\text { kanji }\end{array}$} & 5 & $\begin{array}{l}\text { Penggunaan kanji yang dipelajari sudah efektif untuk keseluruhan } \\
\text { tulisan }\end{array}$ \\
\hline & 4 & Penggunaan kanji yang dipelajari efektif untuk sebagian tulisan \\
\hline & 3 & $\begin{array}{l}\text { Penggunaan kanji kurang efektif tapi ada usaha untuk } \\
\text { menggunakan kanji }\end{array}$ \\
\hline & 2 & Penggunaan kanji tidak efektif sebagian besar salah \\
\hline & 1 & ad \\
\hline
\end{tabular}

Tabel 2: Rubrik Penilaian Karangan 


\begin{tabular}{cc} 
Nilai & Penjelasan \\
\hline 5 & Sangat baik \\
\hline 4 & Baik \\
\hline 3 & Cukup \\
\hline 2 & Tidak baik \\
\hline 1 & Sangat tidak baik
\end{tabular}

Tabel 3 : Skala Penilaian Karangan

\begin{tabular}{|c|c|c|}
\hline $\begin{array}{c}\text { Responden } \\
\text { ke }\end{array}$ & Nilai Pretest & $\begin{array}{l}\text { Nilai } \\
\text { Posttest }\end{array}$ \\
\hline 1 & 64 & 92 \\
\hline 2 & 44 & 60 \\
\hline 3 & 56 & 96 \\
\hline 4 & 52 & 84 \\
\hline 5 & 76 & 96 \\
\hline 6 & 52 & 92 \\
\hline 7 & 56 & 84 \\
\hline 8 & 60 & 88 \\
\hline 9 & 64 & 84 \\
\hline 10 & 48 & 76 \\
\hline 11 & 60 & 92 \\
\hline 12 & 60 & 96 \\
\hline 13 & 52 & 92 \\
\hline 14 & 60 & 92 \\
\hline 15 & 48 & 80 \\
\hline 16 & 40 & 80 \\
\hline 17 & 52 & 96 \\
\hline 18 & 36 & 72 \\
\hline 19 & 56 & 84 \\
\hline$\Sigma$ & 1036 & 1636 \\
\hline $\mathrm{M}$ & 54,5 & 86,1 \\
\hline
\end{tabular}

Tabel 4: Analisis data hasil pretest dan posttest

Tabel 4 menunjukkan bahwa nilai hasil masing-masing responden, nilai total dan nilai rata-rata dapat dilihat di bagian bawah tabel. Ada peningkatan 
yang signifikan dilihat dari nilai rata-rata pretest $(54,5)$ dan nilai rata-rata posttest $(86,1)$. Dengan demikian terbukti bahwa nilai rata-rata pembelajar sebelum dan sesudah menggunakan media audiovisual dari Youtube ada perkembangan dan peningkatan kemampuan dalam menulis sakubun.

\begin{tabular}{cc}
\hline Nilai & Keterangan \\
\hline $86-100$ & Baik Sekali \\
$76-85$ & Baik \\
$66-75$ & Cukup \\
$56-65$ & Kurang \\
$46-55$ & Kurang Sekali \\
$36-45$ & Gagal
\end{tabular}

Tabel 5: Standar Penilaian Pretest dan Posttest

Standar penilaian yang digunakan pada pre-test dan post test seperti yang tertera pada tabel 5. Dengan merujuk pada tabel 4 dan 5, diketahui bahwa nilai rata-rata responden sebelum digunakan media audiovisual (pretest) pada penelitian ini yaitu 54,4 termasuk ke dalam kategori kurang sekali. Setelah diterapkannya treatment menggunakan media audiovisual video dalam menulis sebuah karangan bahasa Jepang, mulailah pemberian posttest dengan materi yang sama seperti materi pada saat pretest. Dari hasil perhitungan nilai rata-rata terbukti adanya dampak dari penerapan media audiovisual Youtube terhadap kemampuan menulis sakubun responden. Walaupun pada saat posttest masih ada responden yang salah menggunakan ungkapan dan tata bahasanya, jika dilihat dari hasil posttest, responden mampu menuliskan karangan lebih dari 400 huruf bahasa Jepang dengan nilai rata-rata kelas 86,10 yang menurut standar penilaian nilai (tabel 5) masuk kategori baik sekali. Yang artinya dengan media audiovisual dapat mempengaruhi pengembagan ide cerita yang responden buat. 
Selanjutnya dari hasil angket secara keseluruhan sangat positif dan jawaban dari angket yang memiliki persentase di atas 60\%, seperti yang terlihat pada tabel 6 .

\begin{tabular}{ll}
\hline \multicolumn{1}{c}{ Pertanyaan } & \multicolumn{1}{c}{ Jawaban } \\
\hline $\begin{array}{l}\text { 1. Setelah digunakannya } \\
\text { media audiovisual apakah } \\
\text { kemampuan sakubun } \\
\text { anda meningkat? }\end{array}$ & $\begin{array}{l}\text { Meningkat : 94,8\% } \\
\text { Tidak Meningkat :5, }\end{array}$ \\
& \\
$\begin{array}{l}\text { 2. Apakah dengan media } \\
\text { audiovisual membantu } \\
\text { anda dalam } \\
\text { mengembangkan ide? }\end{array}$ & Setuju : 94,3\% \\
$\begin{array}{l}\text { Tidak Setuju : 5,7\% } \\
\text { audiovisual, pembelajaran } \\
\text { sakubun menjadi efektif? }\end{array}$ & Tidak Setuju : 5,2\% \\
\end{tabular}

Tabel 6: Hasil Angket

Pada tabel 6 menunjukkan hasil angket yang positif. Sebagian besar responden memilih setuju bahwa penggunaan audiovisual dalam pembelajaran karangan (sakubun). Sebagian besar responden sebanyak $(94,8 \%)$ responden yang menyatakan bahwa sesudah digunakannya media audiovisual kemampuan sakubun responden menjadi meningkat, kemudian sebanyak $(94,3 \%)$ dari responden menyatakan bahwa dengan media audiovisual dalam pembelajaran sakubun membantu pembelajar meningkatkan ide atau gagasan sesuai dengan tema yang ada. Selain itu sebagian besar responden $(94,8 \%)$ reponden menyatakan bahwa media audio visual cocok digunakan dalam pembelajaran menulis karangan bahasa Jepang. Hasil dari nilai tes dan angket diatas sesuai dengan apa yang dikatakan oleh Arsyad (2013) bahwa media audiovisual merupakan alat yang digunakan dalam kegiatan pembelajaran menulis dan berbicara yang bertujuan untuk mentransfer pengetahuan, sikap dan gagasan. 
Berkaitan dengan pernyataan sebelumnya Sadiman, dkk (2012) membuktikan bahwa pembelajaran dengan menggunakan media audiovisual menjadikan pembelajar seolah-olah mendapatkan informasi asli dari sumbernya dan pengalaman langsung. Akan tetapi, penggunaan media audiovisual memiliki kekurangan yaitu komunikasi yang berjalan hanya satu arah, maka peneliti sebagai pengajar harus lebih sering memberi umpan agar pembelajar mau berkomunikasi dua arah. Meskipun terdapat kekurangan dari penelitian ini, akan tetapi dapat disimpulkan bahwa penggunaan media audiovisual Youtube dapat memberikan dampak positif terhadap peningkatan kemampuan menulis sakubun, terutama pada pengembangan dan penuangan ide ke dalam sebuah karangan.

\section{KESIMPULAN}

Berdasarkan pemaparan data di atas maka dapat disimpulkan sebagai berikut:

Berdasarkan analisis data tes memperlihatkan nilai rata-rata kemampuan menulis sakubun sebelum diterapkannya media audiovisual Youtube masuk ke dalam kategori kurang. Hal ini diperkuat oleh analisis hasil karangan pembelajar, yaitu keterbatasan dalam menggunakan kosakata dan tidak ada perluasan gagasan atau ide sesuai tema yang ditentukan. Akan tetapi, setelah diterapkannya media audiovisual Youtube pada proses pembelajaran menulis sakubun, terlihat kemampuan pembelajar dalam menulis sakubun berada di kategori hampir sempurna berdasarkan standar penilaian nilai (tabel 5). Hal ini terbukti dari pengembangan ide, isi karangan yang informatif sesuai dengan tema, dan ditambah juga penggunaan kosakata serta huruf kanji yang tepat. Dan apabila dianalisa berdasarkan hasil belajar terdapat perubahan nilai rata-rata sebelum dan sesudah digunakan media audiovisual Youtube mengalami kenaikan sebesar 31,6 poin. 
Berdasarkan hasil pengolahan angket diketahui bahwa respon pembelajar terhadap penggunaan media audiovisual Youtube pada pembelajaran menulis sakubun mendapatkan tanggapan baik dengan nilai rata-rata 94,5\%. Dengan demikian dapat disimpulkan bahwa penerapan media audiovisual Youtube diasumsikan cocok diimplementasikan pada pembelajaran menulis sakubun karena dapat membantu responden untuk mengembangkan ide sehingga kemampuan menulispun meningkat.

\section{REFERENSI}

Abbas, S. (2006). Pembelajaran bahasa Indonesia yang efektif di sekolah dasar. Depdiknas

Aneros, N. (2012). Pendekatan CTL (contextual teaching \& learning) dalam pembelajaran sakubun. Jurnal Bahasa Asing, 8(8), 63-77

Aneros, N. (2013). Penggunaan furikaeri shito untuk perbaikan pengajaran sakubun. Jurnal Bahasa Asing, 9(9), 67-78.

Anshori, D. S. (2004). "Peningkatan kemampuan menulis mahasiswa melalui model workshop dalam perkuliahan kependidikan pada program non kependidikan jurusan pendidikan bahasa dan sastra Indonesia FPBS UPI". Jurnal Pendidikan Bahasa dan Sastra, 4 (6), 390-403.

Arsyad, A. (2013). Media pembelajaran. PT.Grafindo Persada.

Cahyani, I. (2005). Pengembangan Model Pembelajaran Menulis Bermuatan Kecakapan Hidup untuk Meningkatkan Kebermaknaan Pembelajaran Bahasa Indonesia. Laporan Penelitian Tidak Diterbitkan. Bandung: Lemlit UPI (Lembaga Penelitian Universitas Pendidikan Indonesia).

Hermawan, H. (2007). Media pembelajaran sekolah dasar. UPI Press.

Kempt, J. E., \& Dayton, D. K. (1998). Planning and producing intructional media. Harper \& Row Publishhers.

Novianti, N. (2012). "The implementation of cognitive and constructivism theory in media Activities for sakubun in seventh semester at Bina Nusantara University". Humaniora, 3(1). 
Oomori, M., \& Kono, T. (2013). Sakubun jugyou no tsukurikata. Aruku.

Sadiman, A. dkk. (2012). Media pendidikan: Pengertian dan pemanfaatannya. PT. Rajagrafindo Persada.

Widianti, S. dkk. (2019). Chujyokyu Sakubun (Rencana Pembelajaran Semester). Universitas Pendidikan Indonesia. Tidak diterbitkan 